\title{
PENINGKATAN KAPASITAS TERMAL PENAMPUNG AIR PANAS SOLAR HEATER MENGGUNAKAN CAPSULATED PARAFFIN
}

\author{
Rani Anggrainy ${ }^{1}$, Dibyo Setiawan ${ }^{2}$, Danies Seda Yuseva ${ }^{3}$, Muhammad Nurtanto ${ }^{4}$ \\ ${ }^{1}$ Program Studi Teknik Mesin, Fakultas Teknik, Universitas Krisnadwipayana, \\ ${ }^{2}$ Program Studi Teknik Mesin, Fakultas Teknik, Universitas Mpu Tantular, \\ ${ }^{3}$ Program Studi Teknik Mesin, Fakultas Teknik dan Ilmu Komputer, Universitas Buana Perjuangan \\ ${ }^{4}$ Program Studi Pendidikan Teknik Mesin, Fakultas Keguruan dan Ilmu Pendidikan, Universitas Sultan Ageng Tirtayasa \\ 1rani_anggrainy@unkris.ac.id \\ 2dibyosetiawan@mputantular.ac.id \\ 3denis.seda@ubpkarawang.ac.id \\ 4mnurtanto23@untirta.ac.id
}

\begin{abstract}
Abstrak - Matahari merupakan sumber energi terbarukan yang berkontribusi penting dalam kehidupan manusia untuk kegiatan sehari-hari. Aplikasi pemanas air tenaga matahari secara signifikan mampu mengurangi beban listrik pemanasan air sehingga metode ini secara tidak langsung mampu menghemat kebutuhan energi. Tantangan terbesar adalah meningkatkan densitas energi penyimpanan air hangat. Media penyimpanan terbaik adalah paraffin, namun terkendala terhadap rendahnya konduktivitas termal dari paraffin dan juga media pembungkusnya. Penelitian ini fokus pada upaya perbaikan termal konduktivitas paraffin sebagai media penyimpanan panas dengan mengggunakan campuran nikel pada rasio (volume) $10-50 \%$. Sampel paraffin dan campuran paraffin nikel dimasukan ke dalam pembungkus dari material aluminum 6063 kemudian diuji untuk proses penyerapan dan pelepasan panas. Penyerapan panas terbaik diperlihatkan oleh sampel dengan kandungan nikel paling banyak, sedangkan pada proses pelepasan panas sampel dengan performa terbaik ditunjukkan dengan campuran nikel antara $20-40 \%$. Hasil ini berhubungan langsung dengan power rate dari tiap sampel. Hasil studi ini dapat dijadikan sebagai referensi untuk peningkatan kapasitas termal penyimpanan air hangat dari pemanas air tenaga matahari.
\end{abstract}

Kata Kunci-Encapsulated; Paraffin; PCM; Penyimpanan termal; Solar heater.

\begin{abstract}
Solar power is considered as the most essential renewable energy in human life, particularly for daily activities. The application of solar water heater is significantly able to reduce the electric load of water heating so that this method is indirectly able to save energy needs. The biggest challenge is increasing the energy density of warm water storage. The best storage medium is paraffin, but it is constrained by the low thermal conductivity of the paraffin and also the wrapping media. This study focuses on efforts to improve thermal conductivity of paraffin as a heat storage medium by using nickel mixture at a ratio (volume) of 10 - $50 \%$. Samples of paraffin and nickel paraffin mixture are inserted into the wrapper of aluminum 6063 material and then tested for heat absorption and release process. The best heat absorption is shown by the sample with the most nickel content, while in the heat release process the best performing sample is shown with a nickel mixture between $20-40 \%$. These results are directly related to the power rate of each sample. The results of this study can be used as a reference for increasing the thermal capacity of warm water storage from solar water heaters.
\end{abstract}

Keywords_Encapsulated; Paraffin; PCM; Solar heater; Thermal storage.

\section{PENDAHULUAN}

Krisis energi menjadi isu terpenting pada abad 21. Inovasi dan perkembangan terus dilakukan untuk bisa memaksimalkan serapan energi baru terbarukan dan mengurangi ketergantungan terhadap energi tidak terbarukan [1]. Energi matahari merupakan energi terbarukan yang paling potensial untuk dimanfaatkan sebaik mungkin di Indonesia khususnya [2]. Sebagai negara khatulistiwa, Indonesia mendapat suplai matahari yang tinggi sepanjang tahun sehingga pemanfaatan energi matahari sangat tepat dilakukan di Indonesia [3].
Salah satu aplikasi sederhana dari pemanfaatan energi matahari adalah solar water heater atau pemanas air tenaga matahari [4]. Sistem pemanas air tenaga matahari memanfaatkan pancaran sinar matahari yang diserap oleh kolektor, kemudian panas ini dialirkan ke air yang bersirkulasi [5]. Agar penggunaannya bisa bertahan lebih lama, maka sistem ini dilengkapi dengan penampungan air hangat yang berfungsi sebagai penyimpan kalor [6]. Permasalahannya adalah, penyimpanan panas melalui media air membutuhkan satuan volume yang lebih besar karena sifat pemanasan yang bersifat sensibel, sehingga dibutuhkan volume yang lebih besar per satuan energi yang disimpan [7]. 
Perbaikan sistem penyimpanan termal pada solar water heater umumnya dilakukan dengan memanfaatkan media penyimpanan berbasis Phase Change Material (PCM), seperti paraffin wax [8]. Keuntungan utama dari penggunaan paraffin wax adalah densitas energi yang lebih tinggi pada satuan volume dibandingkan dengan menggunakan air. Permasalahannya adalah paraffin wax memiliki konduktivitas termal yang rendah, dapat terbakar dan rentan bercampur dengan air [9]. Hal ini menjadi tantangan tersendiri dalam proses penempatan paraffin wax pada sistem solar water heater.

Beberapa kajian secara khusus membahas tentang upaya peningkatan aplikasi paraffin wax pada solar water heater. C. Shen, dkk [10] membahas tentang perbaikan paraffin wax untuk bentuk yang lebih stabil dengan menggunakan salt hydrate yang mana perbaikan ini mampu menjaga kekompakan bentuk dari paraffin wax saat memasuki fasa cair dan kembali ke fasa padat. B. Sivapalan, dkk [11] melakukan pengayaan paraffin wax dengan menggunakan nanoemulsion untuk memperbaiki performa perpindahan panas dari paraffin wax pada aplikasi sistem penyimpanan energi. Upaya yang lebih baik dilakukan oleh B. Shang, dkk [12] dengan fokus pada pembuatan composite paraffin dengan mencampur paraffin dengan material yang memiliki konduktivitas termal yang tinggi.

Salah satu poin terpenting yang harus dipertimbangkan dari seluruh upaya pengayaan paraffin wax pada aplikasi solar water heater adalah mempertimbangkan kemudahan dari proses pembuatan dan juga biaya [13]. Hal ini harus dijadikan pertimbangan penting mengingat umumnya solar water heater digunakan pada aplikasi perumahan sehingga poin tersebut harus dijadikan landasan penting. Studi ini fokus pada upaya pengayaan paraffin wax pada aplikasi solar water heater dengan mengkombinasikan paraffin wax menggunakan bungkus encapsulated yang dikombinasikan dengan penambahan material sensibel berbasis nikel. Penggunaan nikel didasari pada karakteristik stabilitas yang baik dan tidak mudah korosi serta pertimbangan harga yang lebih baik.

\section{METODE}

Paraffin wax yang digunakan pada penelitian ini adalah paraffin komersil dengan sifat utama sebagaimana ditunjukkan pada tabel 1 .

Tabel 1. Sifat umum paraffin

\begin{tabular}{|c|c|c|}
\hline No. & Parameter & Nilai \\
\hline 1. & Titik leleh & $60^{\circ} \mathrm{C}$ \\
\hline 2. & Kalor laten & $189 \mathrm{~J} / \mathrm{g}$ \\
\hline 3. & Panas spesifik (padat) & $2.48 \mathrm{~J} / \mathrm{g} . \mathrm{K}$ \\
\hline 4. & Panas spesifik (cair) & $2.76 \mathrm{~J} / \mathrm{g} . \mathrm{K}$ \\
\hline 5. & Densitas & $0.79 \mathrm{gram} / \mathrm{ml}$ \\
\hline
\end{tabular}

Nikel yang digunakan adalah bubuk nikel dengan tingkat kemurnian 99.6\% dengan rerata ukuran butir sebesar 200 mesh $(75 \mu \mathrm{m})$, dengan kalor spesifik $0.44 \mathrm{~J} / \mathrm{g} . \mathrm{K}$ dan densitas $8.8 \mathrm{~g} / \mathrm{cm}^{3}$. Penggunaan ukuran butir yang lebih kecil memberikan keuntungan untuk distribusi partikel yang lebih baik sehingga peningkatan dari konduktivitas termal pada paraffin bisa diperoleh lebih maksimal. Selanjutnya disiapkan enam kategori sampel dengan mempertimbangkan rasio volume antara paraffin dan nikel. Sampel pertama adalah paraffin murni, sampel kedua dan sampai sampel ke enam adalah penambahan nikel sebesar $10 \%$ sampai dengan $50 \%$. Detail sampel ditunjukkan pada tabel 2.

Tabel 2. Detail Sampel

\begin{tabular}{|c|c|c|}
\hline \multirow{2}{*}{$\begin{array}{c}\text { Nama } \\
\text { Sampel }\end{array}$} & Paraffin & Volume (\%) \\
\cline { 2 - 3 } & 100 & 0 \\
\hline $\mathrm{A}_{1}$ & 90 & 10 \\
\hline $\mathrm{A}_{2}$ & 80 & 20 \\
\hline $\mathrm{A}_{3}$ & 70 & 30 \\
\hline $\mathrm{A}_{4}$ & 60 & 40 \\
\hline $\mathrm{A}_{5}$ & 50 & 50 \\
\hline $\mathrm{A}_{6}$ & &
\end{tabular}

Setelah sampel disiapkan, selanjutnya bungkus encapsulated dibuat menggunakan tabung aluminum 6063-T5 dengan nilai densitas $2.69 \mathrm{~g} / \mathrm{cm} 3$ memiliki kalor spesifik 0.9 J/g.K. Detail ukuran dari bungkus encapsulated diperlihatkan pada gambar 1 .

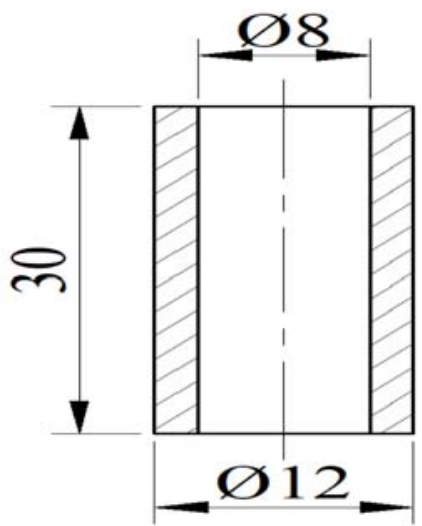

Gambar 1. Detail bungkus encapsulated untuk paraffin dan nikel

Ukuran yang kecil dari bungkus encapsulated bertujuan untuk memaksimalkan distribusi energi pada penampungan air. Dari detail gambar 1, maka diperoleh luas penampang, dan volume isi yakni $1.35 \mathrm{~cm}^{2}$ dan $1.51 \mathrm{~cm}^{3}$.

Kalorimeter model coffee cup digunakan sebagai wadah penampungan untuk media air panas dengan tujuan untuk meminimalisir keluar masuknya panas dari dan ke air panas saat proses pelepasan panas. Volume total yang digunakan kalorimeter adalah $300 \mathrm{ml}$. Volume total dari tiap bungkus adalah $3.39 \mathrm{~cm}^{3}$. Tiap pengujian menggunakan dua puluh bungkus encapsulated dengan total volume maksimal yang digunakan pada kalorimeter adalah $200 \mathrm{ml}$. Total volume air yang digunakan adalah $132 \mathrm{ml}$. Pengukuran dari kalorimeter menggunakan thermocouple tipe $\mathrm{K}$ yang dilakukan pada 4 titik berbeda seperti diperlihatkan pada gambar 2 . 


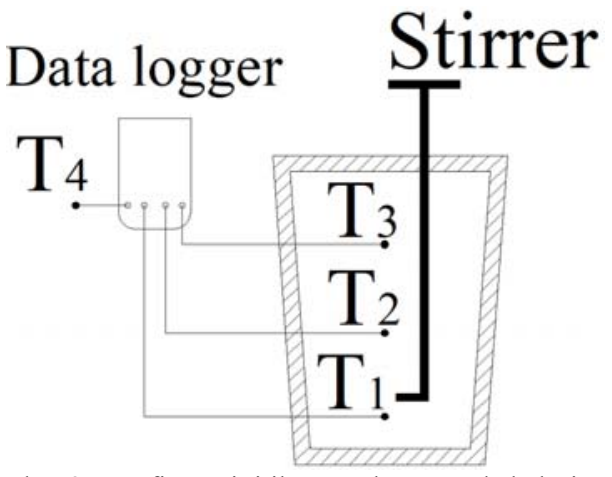

Gambar 2. Konfigurasi titik pengukuran pada kalorimeter

$\mathrm{T}_{1}-\mathrm{T}_{3}$ digunakan untuk mengukur temperatur air di bagian dalam kalorimeter. Tiga titik pengukuran bertujuan untuk menjamin kesetimbangan temperatur pada seluruh bagian kalorimeter. $\mathrm{T}_{4}$ digunakan untuk mengukur suhu udara sekitar. Stirrer digunakan untuk mengaduk air dan juga bungkus encapsulated paraffin untuk mencegah konsentrasi panas yang tidak merata. Pengambilan data dilakukan tiap 30 detik. Deviasi pengukuran dari termometer yang digunakan adalah $0.2 \%$. Seluruh data yang disajikan telah memperhitungkan nilai deviasi tersebut. Proses penyerapan panas dilakukan dengan menggunakan prinsip yang sama. Laju pemanasan dari air dan bungkus encapsulated paraffin dibuat pada laju pemanasan tetap menggunakan plate heater.

\section{HASIL DAN DISKUSI}

Kesetimbangan energi menjadi kunci paling mendasar dalam analisis kapasitas penyimpanan energi termal pada penampungan air hangat. Kapasitas energi yang diterima saat proses penyerapan panas secara teori akan sama dengan kapasitas pelepasan panas saat pelepasan energi. Mempertimbangkan seluruh variabel yang ada serta data teknis yang digunakan pada penelitian ini, maka besarnya energi yang diserap oleh sistem menunjukkan nilai yang berbeda. Total serapan energi dengan massa air sebanyak 132 $\mathrm{ml}$ dengan total perubahan suhu $(\Delta \mathrm{T})$ dari suhu awal $30{ }^{\circ} \mathrm{C}$ hingga suhu maksimal $95^{\circ} \mathrm{C}$ disajikan pada gambar 3 .

Total serapan energi merupakan banyaknya energi kalor yang diserap oleh sistem (dalam hal ini sampel yang digunakan). Serapa energi air lebih sedikit dikarenakan hanya dipengaruhi oleh kalor jenis sensibel air. Sampel $A_{1}$ sampai dengan $\mathrm{A}_{6}$ merupakan total serapan energi gabungan antara air, dan encapsulated paraffin. Sampel $A_{1}$ relatif lebih tinggi dikarenakan tidak menggunakan pengayaan nikel sehingga hanya dipengaruhi oleh panas sensibel pembungkus dan kalor laten paraffin. Sampel $\mathrm{A}_{2}-\mathrm{A}_{6}$ dipengaruhi oleh panas sensibel nikel sehingga nilai total serapan energinya menjadi lebih kecil.

Perbedaan jelas terkait kapasitas energi penyimpanan diperlihatkan antara pada penyimpanan dengan air murni dan menggunakan encapsulated paraffin dimana kapasitas yang disimpan oleh sistem yang menggunakan encapsulated paraffin lebih tinggi dibandingkan dengan air murni. Poin ini menjadi informasi penting karena penggunaan encapsulated paraffin mampu menaikan kapasitas penyimpanan secara signifikan. Kenaikan ini disebabkan oleh sifat paraffin yang memiliki 2 fasa saat proses penyerapan panas yakni fasa padat dan cair dengan nilai kalor lebur yang tinggi. Keuntungan tersebut juga diperkuat dengan penggunaan bungkus encapsulated dari material sensibel tahan karat. Kombinasi metode ini memberikan keuntungan secara signifikan untuk meningkatkan kapasitas penyimpanan energi panas pada sistem.

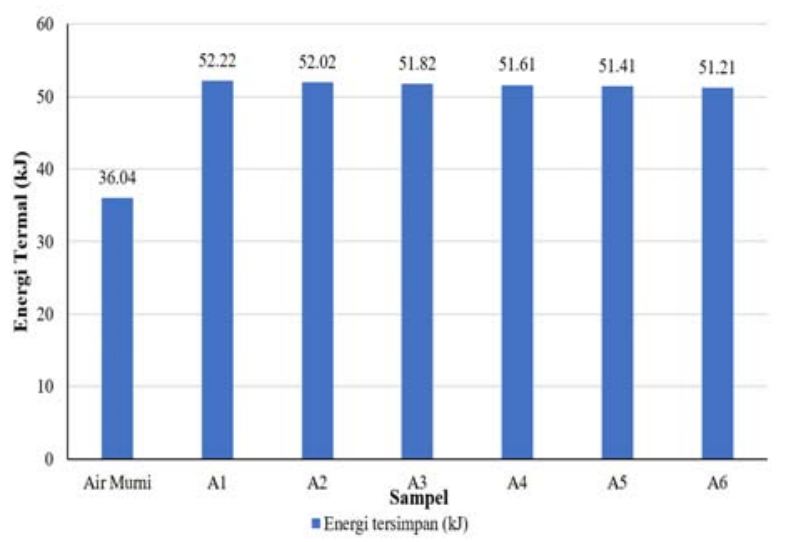

Gambar 3. Serapan energi untuk masing-masing media penyimpanan

Perbedaan energi pada sampel yang menggunakan encapsulated paraffin $\left(\mathrm{A}_{1}-\mathrm{A}_{6}\right)$ menunjukkan pola yang identik yakni kapasitas penyimpanan menurun dari sampel $A_{1}$ sampai dengan sampel $\mathrm{A}_{6}$. Perbedaan ini disebabkan oleh penambahan nikel pada sampel $\mathrm{A}_{2}-\mathrm{A}_{6}$ dimana kapasitas paraffin berkurang seiring dengan penambahan nikel pada sampel. Data ini dengan jelas menunjukkan bahwa kapasitas penyimpanan lebih dipengaruhi oleh total paraffin yang digunakan pada tiap bungkus. Semakin banyak kapasitas paraffin memberikan keuntungan terkait kapasitas penyimpanan energi yang lebih banyak, namun laju pelepasan dan penyerapan panas perlu diketahui karena berkaitan dengan power rate dari sistem penyimpanan.

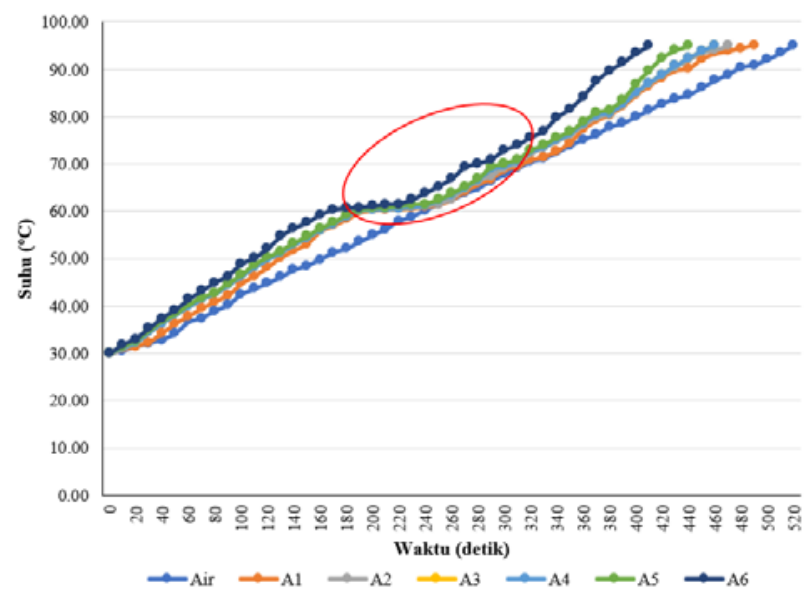

Gambar 4. Grafik karakteristik penyerapan energi 
Grafik karakteristik penyerapan panas ditampilkan pada gambar 4 dalam bentuk hubungan antara waktu dan kenaikan temperatur. Sampel air memiliki karakteristik linear sesuai dengan sifat aslinya yakni sensibel. Hal berbeda ditunjukkan untuk semua sampel yang mengandung paraffin dimana terjadi perlambatan kenaikan temperatur setelah suhu $60{ }^{\circ} \mathrm{C}$. Hal ini disebabkan oleh sifat perubahan fasa pada paraffin dimana kalor laten berperan aktif pada kondisi ini. Kenaikan suhu pada sampel dipengaruhi oleh sifat sensibel dari bungkus encapsulated dan aditif nikel untuk sampel $\mathrm{A}_{2}-\mathrm{A}_{5}$. Sampel dengan kandungan nikel lebih banyak mampu mencapai temperatur target $\left(95{ }^{\circ} \mathrm{C}\right)$ lebih cepat dan menjadi bukti pengaruh dari penambahan material sensibel dengan konduktivitas termal yang baik.

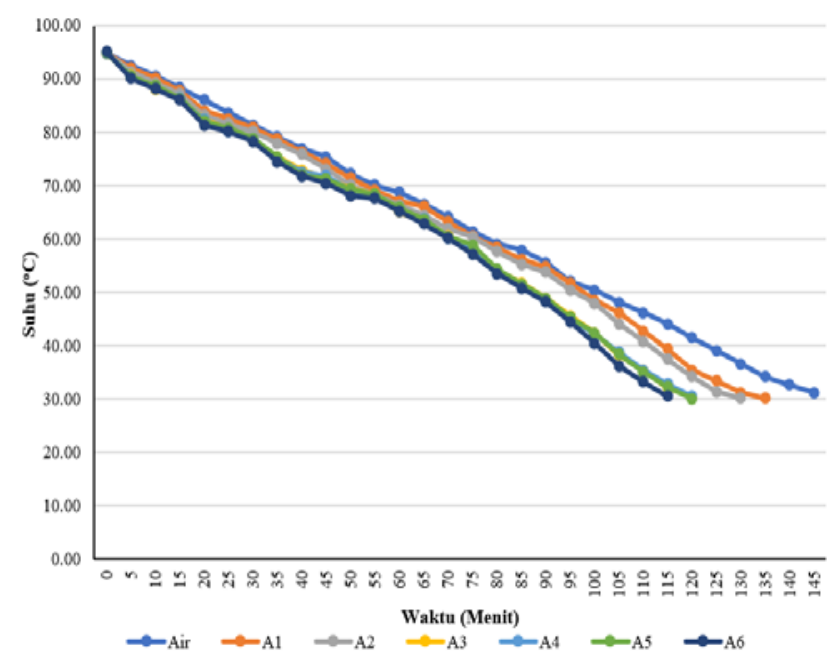

Gambar 5. Grafik karakteristik pelepasan energi

Pola yang cukup berbeda ditunjukan untuk semua sampel campuran nikel dan paraffin saat proses pelepasan panas. Dari gambar 5 terlihat, tidak semua sampel mampu melepas panas secara cepat meskipun saat proses penyerapan panas menunjukkan performa yang baik. Perbedaan ini disebabkan efek fenomena pendinginan cepat (supercooling) yang merupakan salah satu masalah pada sistem paraffin sebagai media penyimpanan termal. Sampel terbaik berdasarkan pengujian pelepasan panas adalah sampel A3, A4 dan A5 dengan laju penurunan panas yang cukup cepat dan derajat pembekuan tidak berbeda secara signifikan saat proses penyerapan panas. hal ini menandakan, rasio penambahan nikel pada sampel paraffin ideal dilakukan pada cakupan nilai tersebut yakni $20-40 \%$ dari volume total sampel yang digunakan.

Aspek terakhir yang perlu dilihat adalah power rate dari tiap sampel, pada kondisi penyerapan dan pelepasan panas. Power rate merupakan suatu istilah yang digunakan untuk menentukan kemampuan material penyimpanan energi untuk melepas dan menyerap panas. Semakin cepat material menyerap panas, maka semakin tinggi nilai power rate material tersebut. Nilai power rate diperoleh berdasarkan banyaknya energi yang diserap atau dilepas dibagi total waktu yang dibutuhkan untuk melepas atau menyerap energi. Nilai serapan energi, grafik karakteristik penyerapan dan pelepasan energi sudah diperoleh sehingga nilai power rate dapat diketahui.

Tabel 3. menyajikan data power rate untuk tiap sampel pada kondisi penyerapan dan pelepasan panas. Meskipun terjadi perbedaan yang signifikan dari power rate saat pelepasan dan penyerapan panas, hal ini tidak merubah kualitas dari nilai tersebut karena pada prinsipnya power rate berkaitan sepenuhnya dengan kemampuan sampel untuk melepas panas sesuai kebutuhan. Terlihat pada penyerapan panas, penambahan nikel berkontribusi langsung terhadap power rate dimana semakin banyak nikel maka semakin tinggi power rate dari sampel.

Tabel 3. Data power rate dari tiap sampel

\begin{tabular}{|c|c|c|}
\hline \multirow{2}{*}{ Sampel } & \multicolumn{2}{|c|}{ Power Rate (W) } \\
\cline { 2 - 3 } & Penyerapan Panas & Pelepasan Panas \\
\hline Air & 98.42 & 5.84 \\
\hline $\mathrm{A}_{1}$ & 106.57 & 6.49 \\
\hline $\mathrm{A}_{2}$ & 110.68 & 6.80 \\
\hline $\mathrm{A}_{3}$ & 112.64 & 7.02 \\
\hline $\mathrm{A}_{4}$ & 112.20 & 7.06 \\
\hline $\mathrm{A}_{5}$ & 116.84 & 7.05 \\
\hline $\mathrm{A}_{6}$ & 124.90 & 7.34 \\
\hline
\end{tabular}

Hubungan berbeda diperlihatkan pada power rate dari tiap sampel saat pelepasan panas. Tidak ada perbedaan signifikan antara sampel $A_{3}-A_{5}$ terkait dengan nilai power rate. Hal ini sesuai dengan grafik model pelepasan panas dari seluruh sampel tersebut dimana laju penurunan panas mendekati waktu yang sama dan juga derajat pembekuan tidak berbeda secara tajam dengan penyerapan panas. Pembekuan yang lebih stabil menandakan penyebaran panas yang lebih baik dan karena nilai konduktivitas termal paraffin lebih baik saat berada pada fasa padat, maka laju penurunan panasnya menjadi lebih baik.

Dari tabel 3 juga terlihat jelasi bahwa power rate dari air murni lebih rendah dibandingkan dengan semua sampel. Hal ini dikarenakan sifat sensibel air dan juga rendahnya konduktivitas termal dari air. Pada poin, terlihat pengaruh dari penambahan encapsulated paraffin pada sistem untuk mampu menaikan power rate air. Hal ini menjadi indikator bahwa penambahan encapsulated paraffin mampu meningkatkan kapasitas termal sistem penyimpanan air panas dan terbukti lebih baik dibandingkan dengan air murni.

\section{KESIMPULAN}

Pemanfaatan paraffin untuk menaikan kapasitas termal penyimpanan air panas untuk pemanas air solar heater menunjukkan hasil yang signifikan dibandingkan dengan menggunakan media air saja. Upaya perbaikan sifat paraffin sebagai media penyimpanan panas dilakukan dengan menggunakan nikel dan juga memanfaatkan media pembungkus dari material dengan konduktivitas termal yang tinggi. Keseluruhan upaya ini secara signifikan mampu menaikan kapasitas termal dari media penyimpanan air hangat. Lebih lanjut, laju pelepasan dan penyerapan panas dari sampel 
campuran paraffin dengan nikel menunjukkan hasil yang lebih baik dibandingkan dengan penggunaan paraffin murni maupun air. Keseluruhan karakteristik dari tiap sampel saat penyerapan dan pelepasan panas yang berkaitan erat juga dengan power rate dari tiap sampel dapat dijadikan referensi penting bagi pengembangan media penyimpanan air hangat yang lebih baik. Kenaikan nilai kapasitas penyimpanan energi mampu membuat penggunaan air hangat yang lebih banyak sehingga densitas energi per satuan volume menjadi lebih baik. Penelitian berikutnya perlu fokus pada pemilihan model alat penukar kalor yang ideal untuk proses pelepasan dan penyerapan panas pada sistem, khususnya untuk kebutuhan yang lebih besar.

\section{UCAPAN TERIMA KASIH}

Penulis ucapkan terima kasih kepada semua pihak yang telah banyak berkontribusi serta mendukung peneliti baik moril maupun materil sehingga terlaksananya penelitian ini.

\section{REFERENSI}

[1] Peinado A, Pliego A, Pedro F, Márquez G. A review of the application performances of concentrated solar power systems. Appl Energy https://doi.org/10.1016/j.apenergy.2019.113893.

[2] Simsek Y, Watts D, Escobar R. Sustainability evaluation of Concentrated Solar Power (CSP) projects under Clean Development Mechanism (CDM) by using Multi Criteria Decision Method (MCDM). Renew Sustain Energy Rev 2018;93:421-38. https://doi.org/10.1016/j.rser.2018.04.090.

[3] Januar R. Comparative Analysis of 20-MW Solar Thermal and $P V$ Power Plant in Rongkop, Indonesia Using LCOE Simulation Method. J Clean Energy Technol 2017;5:383-8. https://doi.org/10.18178/jocet.2017.5.5.402.

[4] Zelzouli K, Guizani A, Kerkeni C. Numerical and experimental investigation of thermosyphon solar water heater. Energy Convers Manag 2014;78:913-22. https://doi.org/10.1016/j.enconman.2013.08.064.

[5] Zou B, Dong J, Yao Y, Jiang Y. An experimental investigation on a small-sized parabolic trough solar collector for water heating in cold areas. Appl Energy 2016;163:396-407. https://doi.org/10.1016/j.apenergy.2015.10.186.

[6] IEA ETSAP, IRENA. Thermal Energy Storage-Insights for Policy Makers 2013:9.

[7] Nivaskarthick R. Analysis of Thermal Energy Storage system using Paraffin Wax as Phase Change Material. Int Conf Innov Eng Technol 2016:38-47.

[8] Dsilva Winfred Rufuss D, Rajkumar V, Suganthi L, Iniyan S. Studies on latent heat energy storage (LHES) materials for solar desalination application-focus on material properties, prioritization, selection and future research potential. Sol Energy Mater Sol Cells 2019;189:149-65. https://doi.org/10.1016/j.solmat.2018.09.031.

[9] Sarbu I, Sebarchievici C, Sarbu I, Sebarchievici C. Chapter 4 Thermal Energy Storage. 2017. https://doi.org/10.1016/B9780-12-811662-3.00004-9.

[10] Shen C, Li X, Yang G, Wang Y, Zhao L, Mao Z, et al. Shapestabilized hydrated salt/paraffin composite phase change materials for advanced thermal energy storage and management. Chem Eng J 2020;385:123958. https://doi.org/10.1016/i.cej.2019.123958.

Rani Anggrainy: Peningkatan Kapasitas Termal Penampung...
[11] Sivapalan B, Neelesh Chandran M, Manikandan S, Saranprabhu MK, Pavithra S, Rajan KS. Paraffin wax-water nanoemulsion: A superior thermal energy storage medium providing higher rate of thermal energy storage per unit heat exchanger volume than water and paraffin wax. Energy Convers Manag 2018;162:109-17. https://doi.org/10.1016/j.enconman.2018.01.073.

[12] Shang B, Hu J, Hu R, Cheng J, Luo X. Modularized thermal storage unit of metal foam/paraffin composite. Int J Heat Mass Transf 2018;125:596-603. https://doi.org/10.1016/j.ijheatmasstransfer.2018.04.117.

[13] Vergura S, Lameira V. Technical-Financial Comparison Between a PV Plant and a CSP Plant. Sist Gestão 2011;6:210 20. https://doi.org/10.7177/sg.2011.v6.n2.a9. 